\title{
Molecular Basis of Altered Enzyme Specificities in a Family of Mutant Amidases from Pseudomonas aeruginosa
}

\author{
By Alistair PATERSON* AND PATRICIA H. CLARKE \\ Department of Biochemistry, University College London, \\ Gower Street, London WC1E 6BT
}

(Received 27 December 1978)

\begin{abstract}
A family of mutant amidases has been derived by experimental evolution of the aliphatic amidase of Pseudomonas aeruginosa strain PACl. Mutation amiE16, in the structural gene for the enzyme, results in the production of the mutant B amidase by strain B6. This strain, unlike the wild-type, can utilize butyramide for growth. Strain B6 gave rise by a single mutational event to strain V9, utilizing valeramide, and strain $\mathrm{PhB3}$, utilizing phenylacetamide. Strain V9 was not itself able to utilize phenylacetamide but gave rise by mutation to the phenylacetamide-utilizing mutant PhV1. Peptide 108 was isolated from chymotryptic digests of mutant amidases from strains B6, PhB3 and PhV1, but could not be detected in chymotryptic digests of the wild-type amidase. The sequence of peptide 108 was established as Met-Arg-His-Gly-Asp-Ile-Phe. Thermolytic digests of mutant amidases from strains B6, PhB3, PhV1 and V9 were compared with digests of the wild-type amidase. A peptide of the composition Met, Arg, His, $\mathrm{Gly}_{2}, \mathrm{Asp}_{3}, \mathrm{Ile}, \mathrm{Ser}_{3}$, Thr, Val was found in the digest of the wild-type amidase and was replaced in the digests of the mutant amidases by a peptide of the composition Met, Arg, His, Gly ${ }_{2}, \mathrm{Asp}_{3}$, Ile, $\mathrm{Ser}_{2}, \mathrm{Thr}$, Val, Phe. Mutation amiE16 is common to the four mutant enzymes and can be accounted for by the mutation Ser $\rightarrow$ Phe. The sequence of the chymotryptic peptide corresponds with the N-terminal sequence of the amidase protein, and can also be related to the thermolysin peptides. It is concluded that mutation amiE16 is a Ser $\rightarrow$ Phe change at position 7 from the $\mathrm{N}$-terminus and the effect of this on the enzyme conformation is discussed.
\end{abstract}

\section{INTRODUCTION}

Wild-type strains of Pseudomonas aeruginosa grow on the short-chain aliphatic amides, acetamide and propionamide. These compounds are inducers and substrates of an amidase that hydrolyses a limited range of low molecular weight amides (Kelly \& Clarke, 1962). The properties of the amidase protein are determined by the structural gene amiE and its synthesis is regulated by positive control exerted by the regulator gene amiR (Farin \& Clarke, 1978). Mutations in amiR may confer an altered amide growth phenotype but this will be within the limits of the amide substrate specificity of the wild-type amidase (A enzyme). Brown et al. (1969) isolated several mutants that grew on butyramide because they produced an amidase with a lower $K_{\mathrm{m}}$ and a higher $V_{\max }$ for butyramide. The parent strain $\mathrm{C} 11$, a spontaneous constitutive mutant derived from the wild-type PAC1, gave rise to strain B6 which produces the mutant B amidase with altered substrate specificity and electrophoretic mobility. From strain B6, a series of valeramide-utilizing mutants were obtained and these produced a heterogeneous group of $\mathrm{V}$ amidases. Unlike the $\mathrm{B}$ amidase, which is similar to $A$ amidase in turnover number and thermal stability, the $\mathrm{V}$ amidases had much lower effective activities (Brown et al., 1969) and were both heat-labile and cold-

* Present address: Department of General Microbiology, University of Helsinki, Malminkatu 20, SF-00100 Helsinki 10, Finland.

$0022-1287 / 79 / 0000-8520 \$ 02.00$ (C) 1979 SGM 


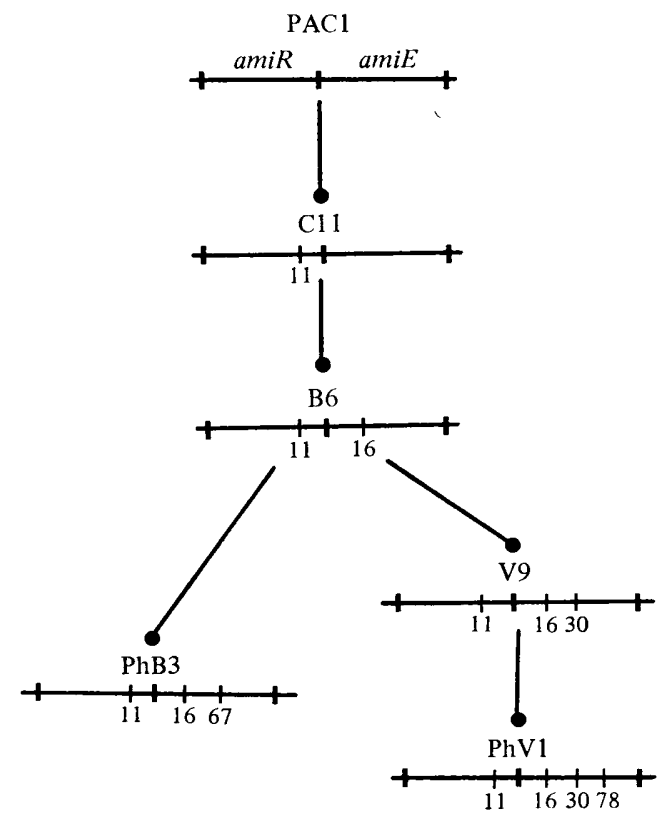

Fig. 1. Genealogy of strains of Pseudomonas aeruginosa producing the mutant amidases described in this paper. Each connecting line represents a single mutational event. Amidase genes $a m i R$ and $a m i E$ indicate the regulator and structural genes, respectively. The numbers of mutations are shown but the gene maps are not to scale.

labile (P. D. Laverack, personal communication). The first mutation, amiE16, appears to have changed the substrate specificity without having any significant effect on the stability of the protein, but the second step mutations in this selection procedure have made the valeramide-utilizing enzymes much less stable and have reduced the overall amidase activity.

Betz \& Clarke (1972) isolated several groups of phenylacetamide-utilizing mutants and described five different phenylacetamidases. Figure 1 indicates that strain $\mathrm{PhB} 3$ was obtained directly from strain B6 while PhV1 was derived from B6 via strain V9. The five phenylacetamidases differed from one another in substrate specificities and in thermal stabilities. It was significant that the amidase of strain PhV1 was more thermostable than the enzyme produced by its parent strain V9, while the amidase of PhV2 (also derived from V9) was among the more thermolabile enzymes.

Strain PhB3 has lost the ability to grow on acetamide because the mutant $\mathrm{PhB} 3$ amidase does not hydrolyse acetamide; strain PhB3 could therefore be used in genetic crosses with amidase-negative mutants carrying negative mutations in amiE. Betz et al. (1974) reported that among the acetamide-positive recombinants obtained in these crosses were some producing $\mathrm{A}$ amidase and others producing $\mathrm{B}$ amidase. The recovery of recombinants producing B amidase indicated that the amiE16 mutation had been conserved during the subsequent evolution of the PhB3 phenylacetamidase. We now present evidence on the nature and site of the amino acid substitution corresponding to amiE16 and confirm that it has been conserved during the evolution of some of the later series of mutant enzymes.

Amidase is a hexameric protein with identical subunits. The molecular weight of the oligomer was found to be 200000 and that of the subunits between 33000 and 35000 (Brown et al., 1973). The mutant amidases are similar to the wild-type enzyme with respect to the molecular weights of the enzymes and their subunits. B amidase cross-reacts completely with antiserum to $\mathrm{A}$ amidase, but the $\mathrm{V}$ amidases and the $\mathrm{Ph}$ amidases cross-react with diffuse bands which is consistent with the decrease in stability of these mutant amidase proteins. 
Table 1. Bacterial strains

$\begin{array}{lllcl}\text { Strain no. } & \text { Series no. } & \text { Amidase } & \text { Amide growth* } & \begin{array}{c}\text { Genotype } \\ \text { PAC1 }\end{array} \\ \text { Wild-type } & \text { A } & \text { A } & \text { amiR } \text { amiE }^{+} \\ \text {PAC142† } & \text { L10 } & \text { A } & \text { A, B } & \text { amiR33 amiE crp-7 } \\ \text { PAC351 } & \text { B6 } & \text { B } & \text { A, B } & \text { amiR11 amiE16 } \\ \text { PAC360 } & \text { V9 } & \text { V9 } & \text { A, B, V } & \text { amiRII amiE16, 30 } \\ \text { PAC377 } & \text { PhB3 } & \text { PhB } & \text { B, V, Ph } & \text { amiR11 amiE16, 67 } \\ \text { PAC388 } & \text { PhV1 } & \text { PhV1 } & \text { B, V, Ph } & \text { amiR11 amiE16, 30, 78 }\end{array}$

* Growth on minimal salt agar plates containing $0.1 \%(w / v)$ acetamide (A), butyramide (B) or valeramide $(\mathrm{V})$ as carbon source or $0.1 \%(\mathrm{w} / \mathrm{v})$ phenylacetamide $(\mathrm{Ph})$ as nitrogen source [with $1.0 \%(\mathrm{w} / \mathrm{v})$ sodium succinate as the carbon source].

$\dagger$ Strain PAC142 is a derepressed mutant producing high levels of wild-type amidase and was the source of all $\mathrm{A}$ amidase preparations.

\section{METHODS}

Bacterial strains. Table 1 lists the strains used for protein studies. Figure 1 shows the genealogy of these and related strains. All mutants were lyophilized immediately after isolation and identification.

Media, growth and preparation of extracts. Methods were as described by Brown et al. (1969) and Brown et al. (1973).

Amidase assays. Assays were carried out during the enzyme purification using the transferase reaction with hydroxylamine (Brammar \& Clarke, 1964). Acetamide was used as the assay substrate for A and B amidases and butyramide was used for V9, PhB3 and PhV1 amidases (Betz \& Clarke, 1972).

Protein assays. The microbiuret method of Itzhaki \& Gill (1964) was used in the early stages of purification and the absorption values at 260 and $280 \mathrm{~nm}$ at the later stages (Warburg \& Christian, 1941). With amidase samples of the highest purity, a value for $A_{280}$ of 1.26 is produced by a solution containing $1 \mathrm{mg}$ enzyme protein $\mathrm{ml}^{-1}$.

Amidase purification. The disrupted bacterial homogenate was agitated with a Silverson Blender and a solution of streptomycin sulphate in buffer was added slowly to give 3 to $4 \mathrm{~g}$ streptomycin per $100 \mathrm{~g}$ wet wt of bacteria. The suspension was left for $30 \mathrm{~min}$ for nucleic acids to precipitate and these were then removed, together with cell debris, by centrifugation at $10000 \mathrm{~g}$ for $40 \mathrm{~min}$ in a Sorvall Superspeed RC2B refrigerated centrifuge. The supernatant was taken as the starting point for estimating recovery of enzyme protein. Normally, little activity was lost in these early stages.

The $\mathrm{A}$ and $\mathrm{B}$ amidases were subjected to heating at $60{ }^{\circ} \mathrm{C}$ which removed a considerable amount of protein with little effect on amidase activity. The temperature and time of heating were reduced for the less thermostable enzymes and in some cases this step had to be omitted entirely. The PhB3 and PhV1 enzymes were heated at $60^{\circ} \mathrm{C}$ for $5 \mathrm{~min}$ and the $\mathrm{V} 9$ enzyme was heated at $50^{\circ} \mathrm{C}$ for $5 \mathrm{~min}$.

The next stage normally involved fractionation with $\left(\mathrm{NH}_{4}\right)_{2} \mathrm{SO}_{4}$, although fractionation with polyethylene glycol gave equally satisfactory results. Assays were carried out on supernatants and precipitates to locate the fraction containing the highest amidase activity; this was normally the protein fraction precipitating between 45 and $65 \%$ saturation with $\left(\mathrm{NH}_{4}\right)_{2} \mathrm{SO}_{4}$ or at 15 and $20 \%(\mathrm{w} / \mathrm{v})$ polyethylene glycol.

The fraction containing the bulk of the amidase activity was dissolved in Tris buffer containing dithiothreitol and dialysed. The samples were loaded on to a column of DEAE-Sephadex previously equilibrated with similar buffer. The column was developed by applying a linear gradient of $\mathrm{KCl}$ from $0 \cdot 15$ to $0.35 \mathrm{M}$ for the $\left(\mathrm{NH}_{4}\right)_{2} \mathrm{SO}_{4}$ fractions and $0 \cdot 15$ to $0.4 \mathrm{M}$ for the polyethylene glycol fractions. The outflow from the column was monitored at $278 \mathrm{~nm}$ with a LKB Uvicord 2 spectrophotometer and collected on an LKB Ultrorac 7000 fraction collector. All columns were run at ambient temperature. The amidase activity appeared as a single protein peak in most preparations. The fractions from the centre of the amidase peak were pooled and precipitated by $80 \%$ saturation with $\left(\mathrm{NH}_{4}\right)_{2} \mathrm{SO}_{4}$.

Criteria of purity. Samples during purification, and from the DEAE-Sephadex columns, were subjected to discontinuous polyacrylamide gel electrophoresis, either as tube gels or as vertical slab gels, using the methods of King \& Laemmli (1971) and Laemmli (1970). The protein bands were stained with Coomassie brilliant blue. Preparations used for peptide analysis gave single bands and were presumed to be $>95 \%$ pure. Several independent preparations were carried out for each amidase protein and yields ranged from 90 to $500 \mathrm{mg}$. 
Protein treatment. The purified amidase was redissolved in $0.2 \mathrm{M}-\mathrm{CH}_{3} \mathrm{COONH}_{4}$ buffer $\mathrm{pH} 8 \cdot 5$, desalted by dialysis or by chromatography on Sephadex G-25, dried in vacuo or with a freeze-drier, and oxidized with performic acid (Hirs, 1956). The denatured protein was lyophilized and redissolved either in $0 \cdot 1 \mathrm{M}-\mathrm{N}$ ethylmorpholine buffer $\mathrm{pH} 8 \cdot 2$ or in $2 \mathrm{M}-\mathrm{NH}_{4} \mathrm{OH}$ followed by dilution and neutralization with acetic acid to $\mathrm{pH} 8 \cdot 5$.

Chymotryptic hydrolysis. Solutions of chymotrypsin (Worthington Biochemical Corporation; 55.4 units $\mathrm{mg}^{-1}$ ) and soya bean trypsin inhibitor (Worthington Biochemical Corporation) in $0.2 \mathrm{M}-\mathrm{CH}_{3} \mathrm{COONH}_{4}$ were mixed to give a preparation containing $10 \mathrm{mg}$ chymotrypsin $\mathrm{ml}^{-1}$ and $1 \mathrm{mg}$ trypsin inhibitor $\mathrm{ml}^{-1}$. The solution was incubated at $37^{\circ} \mathrm{C}$ for $1 \mathrm{~h}$ to inactivate 'tryptic activity' and then stored at $-25^{\circ} \mathrm{C}$. Amidase was hydrolysed by incubating with chymotrypsin (chymotrypsin: amidase molar ratio of $1: 75$ ) at $37^{\circ} \mathrm{C}$ for 4 to $6 \mathrm{~h}$ with occasional shaking. The reaction was terminated either by adding trichloroacetic acid to give a concentration of $5 \%(\mathrm{w} / \mathrm{v})$ or by adjusting to $\mathrm{pH} 4$ with acetic acid. Insoluble residues were removed by centrifugation and the soluble peptides were lyophilized, redissolved in $5 \%(\mathrm{v} / \mathrm{v})$ formic acid and dried over $\mathrm{KOH}$ in vacuo.

Thermolytic hydrolysis. Thermolysin (Calbiochem; 9390 P. U. $\mathrm{mg}^{-1}$ ) was dissolved in $0 \cdot 2 \mathrm{M}^{-} \mathrm{CH}_{3^{-}}$ $\mathrm{COONH}_{4}$ containing $0.025 \mathrm{M}_{-}-\mathrm{CaCl}_{2}$ to give $10 \mathrm{mg} \mathrm{ml}^{-1}$ and stored at $-25^{\circ} \mathrm{C}$. The oxidized amidase was dissolved in a freshly prepared solution of $8 \mathrm{M}$ deionized urea in $0.2 \mathrm{M}-\mathrm{NH}_{4} \mathrm{OH}$. An equal volume of $0.2 \mathrm{M}-$ $\mathrm{CH}_{3} \mathrm{COONH}_{4}$ was added and the mixture was adjusted to $\mathrm{pH} 8 \cdot 5$. Thermolysin (thermolysin:amidase molar ratio of 1:112) was added and the mixture was incubated at $37{ }^{\circ} \mathrm{C}$ for $4 \mathrm{~h}$. The product was lyophilized, redissolved and desalted on a column of Dowex 50 . The solution containing the peptides was lyophilized and the product was redissolved in $5 \%$ formic acid and dried over $\mathrm{KOH}$ in vacuo.

Peptide purification. Soluble peptides were separated by gel filtration on Sephadex G-25, by ion-exchange chromatography or on Sephadex SE-25. High-voltage paper electrophoresis was carried out according to Michl (1951). Buffers used were: pH 6.5, pyridine acetate (Ryle et al., 1955); pH 3.5, pyridine acetate (Ryle et al., 1955); $\mathrm{pH} 1.9$, acetic acid plus formic acid (Atfield \& Morris, 1961). Paper chromatography was carried out with descending solvent, using butanol/acetic acid/water/pyridine at the ratios described in the Results section. Peptides were eluted with $0 \cdot 1 \mathrm{M}-\mathrm{NH}_{4} \mathrm{OH}$.

Thin-layer chromatography for analysing peptide mixtures and purifying individual peptides was done on either Eastman Kodak Chromatogram 6065 cellulose or Merck cellulose $F_{254}$. Ascending solvent systems used were butanol/acetic acid/water/pyridine (5:3:12:10 or 15:3:12:10, by vol.).

Two-dimensional mapping. Peptide mapping of chymotryptic peptides was carried out as described by Brown \& Clarke (1972). Thermolytic peptides were mapped by the method of Chen \& Krause (1975).

Stains for peptides and amino acids. These included $0.25 \%(\mathrm{w} / \mathrm{v})$ ninhydrin in acetone, to which $3 \%(\mathrm{v} / \mathrm{v})$ glacial acetic acid was added before use, $0 \cdot 1 \%$ ninhydrin in butan-1-ol/acetic acid/collidine $(66: 30: 4$, by vol.) and cadmium-ninhydrin (Heathcote \& Washington, 1967). Fluorescamine was used according to Mendez \& Lai (1975), the Pauly reagent for histidine and tyrosine according to Dent (1947), phenanthrenequinone for arginine according to Yamada \& Itano (1966) and proline was detected with isatin.

Analysis of peptides. Peptide samples were hydrolysed in $6 \mathrm{M}-\mathrm{HCl}$ and the resultant amino acid mixture was analysed by $\mathrm{Mr}$ P. D. Laverack using a Locarte analyser. N-terminal analysis was carried out as described by Gray \& Hartley (1963) and peptide sequencing as described by Winter (1977).

\section{RESULTS}

\section{Chymotryptic digests}

Parallel digestions were carried out with performic acid-oxidized preparations of wildtype and mutant amidases and the resultant soluble peptides were separated on Sephadex G-25 into five pools. Digest 1 started from $1.8 \mu \mathrm{mol}$ of A, B6 and PhV1 amidases; Digest 2 started from $1 \cdot 2 \mu \mathrm{mol}$ of $\mathrm{B} 6$ and PhB3 amidases; Digest 3 started from $2 \mu \mathrm{mol}$ of $\mathrm{A}, \mathrm{B} 6$ and $\mathrm{PhB} 3$ amidases.

The peptide pools from each digest were subdivided by preparative paper electrophoresis at $\mathrm{pH} 6.5$ into bands of acidic, basic and neutral peptides. For Digest 1, the bands of charged peptides were separated by paper chromatography using butanol/acetic acid/ pyridine/water (15:3:10:12, by vol.). The neutral peptides were separated by electrophoresis at $\mathrm{pH} 3.5$ followed by chromatography with the above solvent system in the second dimension. For Digests 2 and 3, the charged bands were resolved by electrophoresis at $\mathrm{pH} 3.5$ and, in some cases, at $\mathrm{pH} 1.9$ also. The peptides that were neutral at $\mathrm{pH} 6.5$ were resolved by electrophoresis at $\mathrm{pH} 3 \cdot 5$. Both charged and uncharged peptides were analysed 


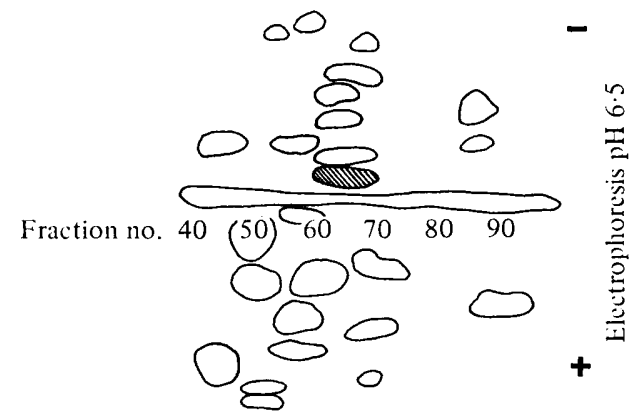

Fig. 2. Map of peptides obtained by filtration of chymotryptic peptides on Sephadex G-25. Fractions were analysed by high-voltage paper electrophoresis at $\mathrm{pH} 6.5$. Chymotryptic peptide 108 in a digest from the mutant B6 amidase is shown by hatching.

further by paper chromatography or by thin-layer chromalography on cellulose using butanol/acetic acid/pyridine/water (15:3:10:12, by vol.). Peptides were stained with $0.2 \%$ ninhydrin or with fluorescamine.

As predicted, most of the peptides observed in the digests of the different enzyme proteins were identical to those of B6. The major difference in the comparison of A and B6 amidases was the absence in the A digest of peptide 108 from the B6 digest. Peptide 108 was located in the Sephadex G-25 Pool 3 and had a very low basic mobility at pH 6.5 (Fig. 2).

Peptide 108 could not be detected in digests of $\mathrm{A}$ amidase in these or subsequent experiments and no peptide could be located in a different position to replace it. Peptide 108 invariably appeared in digests of $\mathrm{B} 6, \mathrm{PhB} 3$ and $\mathrm{PhV} 1$ amidases. The amino acid compositions of the major peptides were analysed routinely and values for peptide 108 from B6 and PhB3 are given in Table 2.

\section{Thermolytic digests}

Hydrolysis with chymotrypsin gave poor yields of soluble peptides which seemed likely to be the result of hydrophobic interactions within regions of the polypeptide. It was hoped that digestion with thermolysin in the presence of $4 \mathrm{M}$-urea might result, not only in cleavage of the polypeptide at more sites, but also in a higher yield of soluble peptides.

Digest 1 of $\mathrm{A}$ and $\mathrm{PhV} 1$ amidases was followed by ion-exchange chromatography on SP-Sephadex C-25 using $\mathrm{HCOONH}_{4}$ and $\mathrm{CH}_{3} \mathrm{COONH}_{4}$ buffers for elution. The fractions from the column were pooled and the peptides were mapped by chromatography and electrophoresis. The yield of peptides from the thermolysin digestion was satisfactory for further peptide analysis and a total of 68 ninhydrin-staining and 85 fluorescamine-staining peptides were detected. The ion-exchange chromatography had not given a clear-cut separation into peptide pools and was replaced in later thermolysin digests by gel filtration.

In Digest $2,3 \mu \mathrm{mol}$ of $\mathrm{A}$ and PhV1 amidases and $2 \mu \mathrm{mol} \mathrm{PhB} 3$ amidase were oxidized with performic acid at a concentration calculated to be equimolar with respect to the cysteine plus methionine residues of the amidase. The solution of amidase protein $(4 \mathrm{mg}$ $\mathrm{ml}^{-1}$ ) in freshly deionized $10 \mathrm{M}$-urea, to which had been added $5 \%$ (w/v) $2 \mathrm{M}-\mathrm{NH}_{4} \mathrm{OH}$, was adjusted to $\mathrm{pH} 8.5$ with $\mathrm{CH}_{3} \mathrm{COOH}$ and diluted with $\mathrm{CH}_{3} \mathrm{COONH}_{4}$, to give a final concentration of $4 \mathrm{M}$-urea. After digestion, the product was lyophilized, redissolved and desalted on a column of Dowex 50. The soluble peptides were fractionated on Sephadex G-25 into seven pools (Fig. 3).

The peptides from each pool were separated by electrophoresis at $\mathrm{pH} 6.5$ into acidic, basic and neutral. The charged peptides were subjected to electrophoresis in a second dimension at $\mathrm{pH} 1.9$ and the neutral peptides to chromatography followed by electrophoresis at $\mathrm{pH} 1.9$.

The thermolysin peptides were stained sequentially with fluorescamine, cadmiumninhydrin and the Pauly reagent. Duplicate maps were prepared and stained only with 
赵 ก สิ

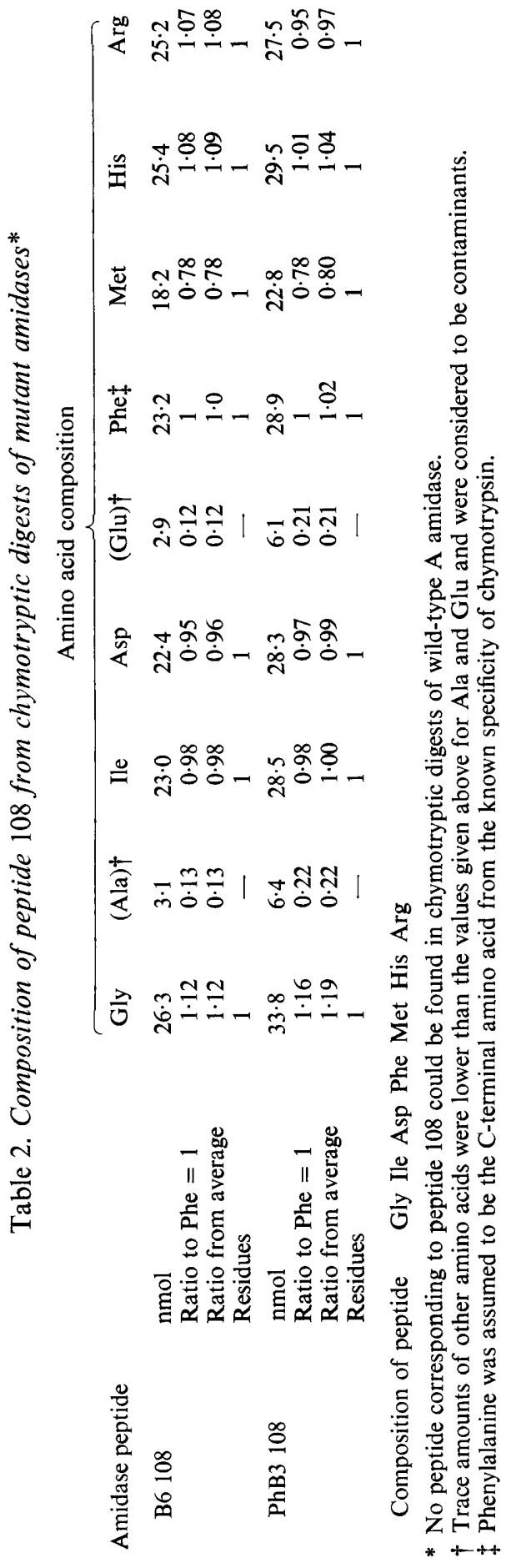




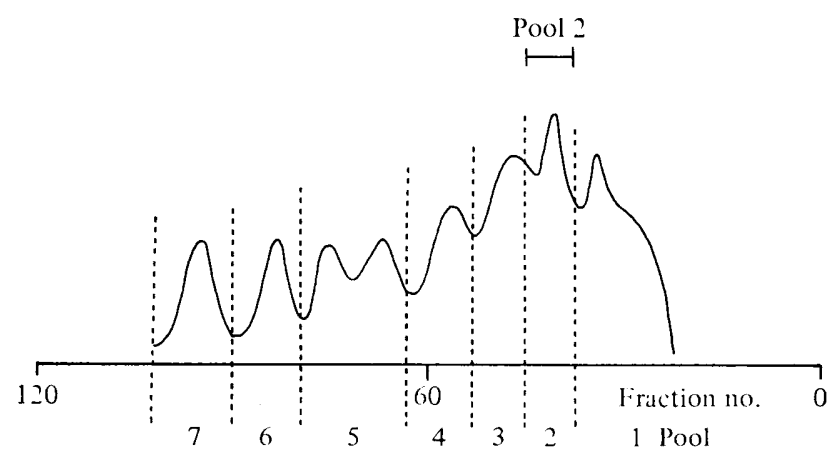

Fig. 3. Gel filtration profile of thermolytic peptides. The digest of mutant PhB3 amidase was fractionated on Sephadex G-25 to give seven peptide pools.

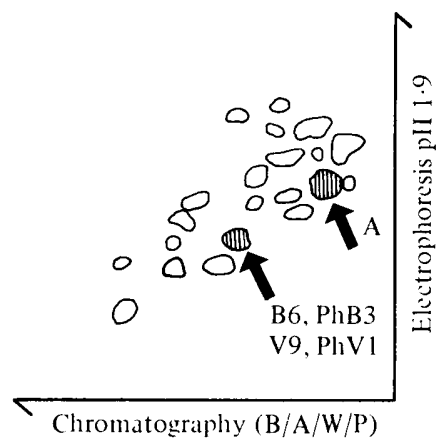

Fig. 4. Peptide map of Pool 2 neutral peptides from thermolytic digests of wild-type and mutant amidases. The position of the peptide from $\mathrm{A}$ amidase, and the position of the corresponding peptides found in mutants B6, PhB3, V9 and PhV1 amidases, is shown by hatching. Paper chromatography with butanol/acetic acid/water/pyridine (B/A/W/P; 15:3:12:10, by vol.) was carried out in the first dimension followed by electrophoresis at $\mathrm{pH} 1.9$.

fluorescamine to preserve the N-terminal amino acids. Any peptides that appeared at different positions in the maps prepared from the wild-type and mutant amidases were eluted and the amino acid compositions were determined. The most striking difference occurred in the map of Pool 2 neutral peptides (Fig. 4). A histidine-containing peptide, distinctive by its staining with the Pauly reagent, was altered in its position on the maps of the mutant $\mathrm{PhVl}$ and $\mathrm{PhB} 3$ hydrolysates.

Digest 3 was carried out in the same way as Digest 2, starting with $2 \mu \mathrm{mol}$ B6 amidase and $1 \mu \mathrm{mol}$ V9 amidase. The Pool 2 neutral peptides were examined and the digests of B6 and V9 were found to contain the same peptide as in the PhB3 and PhV1 digests (Fig. 4). The analyses of the mutant peptides and the corresponding wild-type peptide are shown in Table 3. The mutant peptides all contain a phenylalanine residue which appears to have replaced one of three serines in the corresponding wild-type peptide. The phenylalanine substitution has given an additional site for chymotrypsin cleavage and can account for the additional peptide observed in the chymotryptic digests of the mutant amidases.

\section{Position of amiEl6 substitution}

Figure 1 shows the derivation of the mutants producing amidases in which the substitution of a serine residue by a phenylalanine residue has occurred. The common mutation of these mutants is amiE16 which was the original mutation giving rise to the mutant B enzyme. The altered mobility thermolytic peptides and the extra chymotryptic peptide 108 were found 


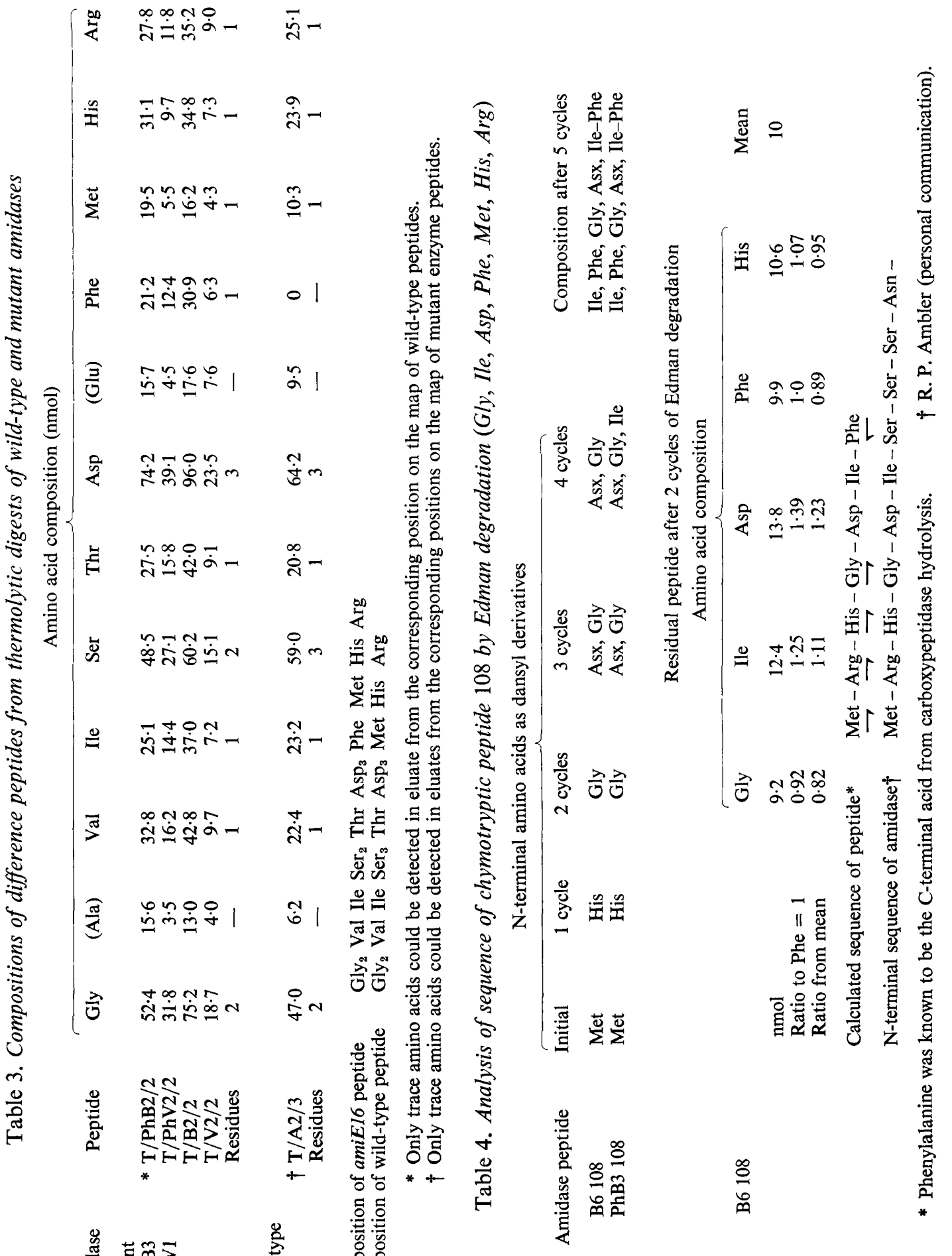


in all the mutant amidases examined, indicating that the phenylalanine substitution corresponded to the mutation amiE16.

Peptide 108 was prepared in sufficient quantity for sequence determination by dansylEdman degradation. The results of the sequence analysis are given in Table 4. After four degradative cycles the residue was dansylated to determine the residual $\mathrm{N}$-terminal amino acid and the remaining amino acids were dansylated after hydrolysis to identify them. The C-terminal amino acid was confirmed as phenylalanine by release on digestion with carboxypeptidase. The position of the arginine residue was not clear from the dansyl-Edman degradation but was established by amino acid composition determination of a portion of peptide after two cycles of subtractive-Edman degradation. The amino acid composition of the degraded residual peptide is shown in Table 4. Methionine had previously been identified at the $\mathrm{N}$-terminus of peptide 108 and this result confirms that arginine is the adjacent residue.

Sequence studies on the polypeptide chain are being carried out in R. P. Ambler's laboratory in Edinburgh. We are grateful to A. Auffret and R. P. Ambler for the information that the $\mathrm{N}$-terminus sequence of the wild-type amidase corresponds to that shown in Table 4.

\section{DISCUSSION}

We have shown that the structural gene mutation amiE16 is a Phe/Ser substitution. This can be accounted for by a $\mathrm{C} \rightarrow \mathrm{U}$ transition in the second position of the codon (Ser, $\mathrm{UC}_{\mathrm{C}}^{U}$ : Phe, $U U_{C}^{U}$ ). The substitution is conserved during the subsequent evolutionary events that extend the substrate specificity of the enzyme to include valeramide and phenylacetamide. This substitution occurs at position 7 and could be assigned with certainty since the chymotryptic peptide is otherwise homologous with the N-terminal sequence of the polypeptide of the wild-type amidase. Brown (1969) had predicted that amiE16 was near the $\mathrm{N}$-terminus from the close genetic linkage found between this marker and markers in the adjacent amiR gene. This finding is important in attempting to understand the effect of small changes in particular regions of the amino acid sequence on the properties of the enzyme protein. It is unlikely that the $\mathrm{N}$-terminal sequence is directly involved in the formation of the active site and it is more likely that this region participates in essential protein folding. The effect of the substitution at residue 7 is to be sought in a change in the enzyme conformation.

Brown et al. (1969) reported that the $K_{\mathrm{m}}$ of B amidase for butyramide in the transferase reaction was $73.7 \mathrm{~mm}$ compared with $500 \mathrm{~mm}$ for A amidase and that the $V_{\max }$ in this reaction was enhanced about 10 -fold. The $B$ amidase differed significantly from A amidase in electrophoretic mobility on starch gels, but examination of tryptic and chymotryptic digests did not reveal any changes in charged amino acids. We suggest that the Phe/Ser substitution results in a slight alteration in the folding of the polypeptide chain which may be due to the loss of a potential hydrogen bond and to the insertion of the bulkier hydrophobic group. The molecular displacement allowing a better orientation of butyramide at the active site of $\mathbf{B}$ amidase than at that of $\mathrm{A}$ amidase is presumably very small since valeramide is not an effective substrate of either enzyme. If the $\mathrm{N}$-terminal sequence is folded within the enzyme structure, the Ser/Phe substitution might change the conformation to enlarge the pocket around the substrate binding site. There are now several reports that single site mutations can result in changes in substrate specificity (Hall, 1977; Hartley et al., 1976) although it had previously been suggested that multiple mutations might be required (Koch, 1972; Hartley, 1974). Mutants of Pseudomonas aeruginosa producing an altered amidase that allowed growth on acetanilide were isolated by Brown \& Clarke (1972) who reported that the amidase of strain AI3 had a single amino acid substitution of Ile/Thr. 
AI3 amidase is slightly less thermostable than A and $B$ amidases but has retained high activity and gives complete cross-reaction in immunodiffusion tests against antiserum to $\mathrm{A}$ and $\mathrm{B}$ amidases. The precipitin lines fused completely with those for $\mathrm{A}$ and $\mathrm{B}$ amidases indicating that the structure had not been altered very much.

Brown (1969) was unable to isolate valeramide-utilizing mutants directly from wild-type PAC1, or from the constitutive strain $\mathrm{C} 11$, either spontaneously or after chemical mutagenesis. On the other hand, valeramide-utilizing mutants were isolated spontaneously from strain B6 at a frequency of about $10^{-8}$. Although PhB3 was isolated after mutagenesis of strain B6 with ethyl methanesulphonate (Betz \& Clarke, 1972), other phenylacetamideutilizing mutants, which appeared to produce an identical enzyme, were isolated at a spontaneous frequency of about $10^{-8}$. The two phenylacetamide-utilizing mutants $\mathrm{PhV} 1$ and $\mathrm{PhV} 2$, isolated from the valeramide-utilizing mutant V9, also arose spontaneously at a similar frequency. No phenylacetamide-utilizing mutants were isolated directly from wild-type PACl, C11 or L10, although mutants producing very thermolabile amidases were isolated after mutagenesis from a butyramide-resistant, constitutive mutant, CB4, and from an amidase-negative mutant, LAm1.

During a long period of evolution bacteria have evolved enzymes that allow growth in a particular ecological niche. In general, compounds that occur frequently in nature are good growth substrates and are readily attacked by the appropriate enzymes. Studies on the metabolism of natural and unnatural pentoses and pentitols have illustrated this and also shown that the enzyme ribitol dehydrogenase can be altered under selection pressure to attack the unnatural pentitol, xylitol, at a higher efficiency (Mortlock, 1976; Hartley et al., 1976).

In our studies on experimental amidase evolution we have found that successive mutations can give rise to mutant amidases that can hydrolyse amides with larger side-chains. We suggest that in the family of mutant amidases we have described in this paper the initial amiEI6 mutation has not only introduced a flexibility into the enzyme protein that allows butyramide to be accepted, but also makes it possible for subsequent mutations at other sites leading to new substrate activities to be introduced more readily.

We thank P. D. Laverack for carrying out the amino acid analyses and A. Kakas for operating some of the fermenter runs. Dr R. P. Ambler was a constant source of advice and encouragement and we are grateful to him and to Dr A. Auffret for permission to quote results on the sequence of the wild-type amidase. This work was supported by grants from the Science Research Council B/RG/62676, GR/A/1164.2 and GR/A/40413.

\section{REFERENCES}

Atfield, G. N. \& Morris, C. J. O. R. (1961). Analytical separations by high-voltage electrophoresis. Biochemical Journal 81, 606-614.

Betz, J. L. \& Clarke, P. H. (1972). Selective evolution of phenylacetamide-utilizing strains of Pseudomonas aeruginosa. Journal of General Microbiology 73, 161-174.

Betz, J. L., Brown, J. E., Clarke, P. H. \& Day, M. (1974). Genetic analysis of amidase mutants of Pseudomonas aeruginosa. Genetical Research 23, 335-359.

Brammar, W. J. \& Clarke, P. H. (1964). Induction and repression of Pseudomonas aeruginosa amidase. Journal of General Microbiology 37, 307-319.

BRown, J. E. (1969). Regulator and structural gene mutants of Pseudomonas aeruginosa amidase. Ph.D. thesis, University of London.
Brown, P. R. \& Clarke, P. H. (1972). Amino acid substitution in an amidase produced by an acetanilide-utilizing mutant of Pseudomonas aeruginosa. Journal of General Microbiology 70, 287 298.

Brown, J. E., Brown, P. R. \& Clarke, P. H. (1969). Butyramide-utilizing mutants of Pseudomonas aeruginosa 8602 which produce an amidase with altered substrate specificity. Journal of General Microbiology 57, 273-295.

Brown, P. R., SMyth, M. J., Clarke, P. H. \& Rosemeyer, M. A. (1973). The subunit structure of the aliphatic amidase from Pseudomonas aeruginosa. European Journal of Biochemistry 34, 177-187.

Chen, K. C. S. \& Krause, R. M. (1975). A peptide mapping technique - a three map system. Analytical Biochemistry 69, 180-186. 
DENT, C. E. (1947). The amino-aciduria in Fanconi syndrome. A study making extensive use of techniques based on paper partition chromatography. Biochemical Journal 41, 240-253.

Farin, F. \& Clarke, P. H. (1978). Positive regulation of amidase synthesis in Pseudomonas aeruginosa. Journal of Bacteriology 135, 379-392.

Gray, W. R. \& Hartley, B. S. (1963). A fluorescent end-group reagent for proteins and peptides. Biochemical Journal 89, 59P.

HaLl, B. G. (1977). The number of mutations required to evolve a new lactase function in Escherichia coli. Journal of Bacteriology 129, 540-543.

Hartley, B. S. (1974). Enzyme families. Symposia of the Society for General Microbiology 24, 151182.

Hartley, B. S., Altosaar, L., Dothie, J. M. \& NEUBERGER, M. S. (1976). Experimental evolution of a xylitol dehydrogenase. In Structure-Function Relationships of Proteins, pp. 191-200. Edited by R. Markham \& R.W. Horne. Amsterdam: North-Holland.

Heathcote, J. G. \& Washington, R. J. (1967). A simple quantitative method for the determination of small amounts of amino acids. Analyst 92, 627-633.

HiRs, C. H. W. (1956). The oxidation of ribonuclease with performic acid. Journal of Biological Chemistry 219, 611-621.

ITZHAKI, R. F. \& GiLL, D. M. (1964). A microbiuret method for estimating proteins. Analytical Biochemistry 9, 401-410.

Kelly, M. \& Clarke, P. H. (1962). An inducible amidase produced by a strain of Pseudomonas aeruginosa. Journal of General Microbiology 27, 305-316.

KING, J. \& Laemmli, U. K. (1971). Polypeptides of the tail fibres of bacteriophage T4. Journal of Molecular Biology 62, 465-477.

КосH, A. L. (1972). Enzyme evolution 1. The importance of untranslatable intermediates. Genetics 72, 297-316.

LAEMMLI, U. K. (1970). Cleavage of structural proteins during the assembly of the head of bacteriophage T4. Nature, London 227, 680-685.

MENDEZ, E. \& LAI, C. Y. (1975). Reaction of peptides with fluorescamine on paper after chromatography or electrophoresis. Analytical Biochemistry 65, 281-292.

Michl, H. (1951). Über Papierelektrophorese bei Spannungsgefällen von $50 \mathrm{~V} / \mathrm{cm}$. Monatshefte für Chemie 82, 489-493.

MoRTLOCK, R. P. (1976). Catabolism of unnatural carbohydrates by microorganisms. Advances in Microbial Physiology 13, 1-53.

Ryle, A. P., SANGer, F., Smith, L. F. \& Kitai, R. (1955). The disulphide bonds of insulin. Biochemical Journal 60, 541-556.

WARBURG, O. \& Christian, W. (1941). Isolierung und Kristallisation des Gärungsferments Enolase. Biochemische Zeitschrift 310, 384-421.

WINTER, G. P. (1977). The amino acid sequence of tryptophanyl tRNA synthetase from Bacillus stearothermophilus. Ph.D. thesis, University of Cambridge.

Yamada, S. \& Itano, H. A. (1966). Phenanthrenequinone as an analytical reagent for arginine and other monosubstituted guanidines. Biochimica et biophysica acta 130, 538-540. 